https://doi.org/10.11646/phytotaxa.487.1.5

\title{
Triandra pellabergensis (Hyacinthaceae subfam. Urgineoideae), a new genus and species from Pella se Berge, Northern Cape Province, South Africa
}

\author{
MARIO MARTÍNEZ-AZORÍN ${ }^{1,5 *}$, MANUEL B. CRESPO ${ }^{1,6}$, MARÍA ÁNGELES ALONSO-VARGAS ${ }^{1,7}$, \\ NEIL R. CROUCH ${ }^{2,3,8}$ \& MICHAEL PINTER ${ }^{4,9}$ \\ ${ }^{1}$ Depto. de Ciencias Ambientales y Recursos Naturales (dCARN), Universidad de Alicante, P. O. Box 99, E-03080 Alicante, Spain. \\ ${ }^{2}$ Biodiversity Research Monitoring and Assessment, South African National Biodiversity Institute, PO Box 701265, Overport 4067, \\ Durban, South Africa. \\ ${ }^{3}$ School of Chemistry \& Physics, University of KwaZulu-Natal, Durban 4041, South Africa. \\ ${ }^{4}$ Institute of Biology, NAWI Graz, Division Plant Sciences, Karl-Franzens University Graz, Holteigasse 6, 8010 Graz, Austria. \\ 5 ["mmartinez@ua.es; ○ https://orcid.org/0000-0002-2605-9575 \\ 6 [”"crespo@ua.es; @ https://orcid.org/0000-0002-3294-5637 \\ 7 !"ma.alonso@ua.es; ‘ https://orcid.org/0000-0003-3768-9203 \\ 8 झ"N.Crouch@sanbi.org.za; 1 https://orcid.org/0000-0002-4938-5840 \\ 9 ”michael.pinter@uni-graz.at; @ https://orcid.org/0000-0002-6055-6989 \\ *Author for correspondence
}

\begin{abstract}
Within the framework of a taxonomic revision of subfamily Urgineoideae based on morphological, genetic and phytogeographic data covering numerous samples from its whole range of distribution, we here describe a new genus and species from Pella se Berge in northwestern South Africa. Triandra gen. nov. is easily characterized by the absence of stamens associated with the outer tepal whorl, therefore having only three stamens per flower, a character previously unknown in Hyacinthaceae. Triandra pellabergensis sp. nov. produces hypogeal bulbs with filiform proteranthous leaves, spurred bracts, lax racemes with few, nodding, nocturnal flowers and erect capsules with the withered tepals persisting atop. The new species resembles Urginea revoluta in general morphology, although this latter species has six stamens per flower, a different seed morphology, a distinct phytogeographic pattern, and a distant phylogenetic relationship. A complete morphological description is presented for the new genus and species, including data on its biology, ecology and distribution.
\end{abstract}

Keywords: Asparagaceae, Drimia, Urginea, Scilloideae, taxonomy, distribution

\section{Introduction}

Family Hyacinthaceae comprises about 1000 species of bulbous plants mostly distributed in Africa, Europe and Asia, with a single genus, Oziroë Rafinesque (1837: 53), present in South America (Speta 1998a, 1998b, APG 2003). Within Hyacinthaceae, four monophyletic subfamilies are accepted: Hyacinthoideae, Ornithogaloideae, Oziroëoideae and Urgineoideae (Speta 1998b, Pfosser \& Speta 1999, Manning et al. 2004, Martínez-Azorín et al. 2011). Alternatively, Hyacinthaceae is treated as Asparagaceae subfamily Scilloideae, and consequently the former subfamilies are reduced to the tribes Hyacintheae, Ornithogaleae, Oziroëeae and Urgineeae (APG 2009, APG 2016, Chase et al. 2009); we favour the former treatment based on morphology.

Generic circumscription of Urgineoideae has been especially controversial in recent decades (Martínez-Azorín et al. 2013, 2017, 2018a, 2019a, 2019b, Pinter et al. 2013, Crouch \& Martínez-Azorín 2015). On the one hand, Manning et al. (2004) presented a radical treatment, recognising only two genera for the whole subfamily: Bowiea Harvey ex Hooker (1867: t. 5619) and Drimia Jacq. ex Willdenow (1799: 165), the latter being extremely broad in morphology and including in synonymy several traditionally accepted genera which are identified by unique syndromes of morphological characters, such as Litanthus Harvey (1844: 314), Rhadamanthus Salisbury (1866: 37), Rhodocodon Baker (1880: 280), Schizobasis Baker (1873a: 105), Tenicroa Rafinesque (1837: 52), Thuranthos Wright (1916: 233) and Urginea Steinheil (1834: 321). On the other hand, Speta (1998a, 1998b, 2001) and Pfosser \& Speta (2001) favoured a more refined approach, in which about 20 different genera were accepted. However, several of 
these genera have been shown or interpreted to be para- or polyphyletic (Pfosser \& Speta 2001, 2004, Manning et al. 2004, Pfosser et al. 2012). Similarly, contrasting taxonomic treatments were recently proposed in subfamily Ornithogaloideae (Speta 1998a, Manning et al. 2004, 2009, Martínez-Azorín et al. 2011). However, when sufficient plastid and nuclear DNA regions are included in the phylogenetic analyses, consistent morphological elements are fully congruent with clades, and these can be accepted at the generic rank, as shown by Martínez-Azorín et al. (2011). A similar taxonomic, morphologic and phylogenetic study in Urgineoideae combining four plastidial and one nuclear regions, covering 293 samples, ca. 160 species and $80 \%$ of total diversity in the subfamily is ongoing, that supports the recognition of a multigeneric treatment of the subfamily (Martínez-Azorín et al. submitted). Based on this evidence, some new genera have been recently described in Urgineoideae, viz. Aulostemon Martínez-Azorín et al. (2017: 288), Austronea Martínez-Azorín et al. (2018a: 105), Iosanthus Martínez-Azorín et al. (2019a: 584), Mucinaea Pinter et al. (2013: 296), Sagittanthera Mart.-Azorín, M.B.Crespo, A.P.Dold \& Van Jaarsv. in Martínez-Azorín et al. (2013: 46), Striatula Pinter et al. (2019: 93), Vera-duthiea Speta (2016: 154) and Zingela Crouch et al. (2018: 36), given their distinct morphologies (Martínez-Azorín et al. 2013, 2017, 2018a, Pinter et al. 2013, 2019, Speta 2016, Crouch et al. 2018) and isolated positions in the phylogenetic trees (Martínez-Azorín et al. submitted).

Our field work in southern Africa during August 2016 resulted in the discovery of a remarkable new urgineoid species, found in gravelly soil at base of large south-facing cliffs on Pella se Berge, a distinctly elevated mountain situated in Northern Cape Province, South Africa (Fig. 1). The site is close to the Orange River and South Africa's northwestern border with Namibia. The new species shows a unique character in Hyacinthaceae, producing only three stamens associated with the inner tepal whorl, a feature that has in part informed the description of the new genus Triandra, at present monotypic. This solution is also supported by its phylogenetic relationships, as it constitutes an isolated lineage in Urgineoideae which is sister to the Madagascan endemic Rhodocodon (Martínez-Azorín et al. submitted), which shows very different morphology and a disjunct distribution. Triandra pellabergensis sp. nov. produces solitary hypogeal bulbs with compact scales, filiform proteranthous leaves, spurred bracts, lax racemes with few, nodding, nocturnal flowers with reflexed tepals, erect capsules with the withered tepals atop and flattened, winged seeds. The new species resembles Urginea revoluta Duthie (1928: 9) (=Drimia hesperantha Manning \& Goldblatt 2003: 111) in general morphology, although the latter species consistently produces six stamens per flower, irregularly compressed, smaller seeds, and differs clearly in its phylogenetic relationships (Martínez-Azorín et al. submitted), ecology and biogeography. A complete morphological description is presented for the new genus and species, with discussion on its biology, ecology, distribution and phylogenetic relationships.

\section{Material and methods}

Detailed morphological studies were undertaken on wild and cultivated specimens and herbarium material following the terminology used for species of Hyacinthaceae in Martínez-Azorín et al. (2007, 2009). Herbarium specimens from the herbaria ABH, BOL, GZU, GRA, K, NBG and PRE (acronyms according to Thiers 2021) were studied. Authors of the cited taxa follow IPNI (2021). Orthography of geographical names and grid-number system follows Leistner \& Morris (1976).

\section{Results}

Triandra Mart.-Azorín, M.B.Crespo, M.Á.Alonso, N.R.Crouch \& M.Pinter gen. nov.

\section{Typus generis: Triandra pellabergensis Mart.-Azorín, M.B.Crespo, M.Á.Alonso, N.R.Crouch \& M.Pinter}

Diagnosis: Triandra shows a unique combination of characters in Hyacinthaceae: filiform leaves; small, nodding, nocturnal flowers with three stamens; filiform, erect filaments; narrowly subclavate, erect style; erect capsule with withered perianth atop; and ellipsoid, flattened, winged seeds.

Description: Small bulbous geophyte. Bulb hypogeal, solitary. Leaves withered at flowering time, filiform, spreading and somewhat curved. Inflorescence a lax, elongate raceme, with few nodding, nocturnal flowers; bracts small, shorty spurred. Bracteoles absent. Tepals 6, biseriate, free or only very shortly connate at base, narrowly lanceolate, whitish with central longitudinal brown stripe on the abaxial side, strongly reflexed at full anthesis. 
Stamens 3, associated with the inner tepal whorl; filaments filiform, white, erect and approaching the style at anthesis; anthers yellow, ovate, encircling the style, dehiscing longitudinally along their whole length, with yellow pollen. Ovary pale yellowish-green, ovoid, 3-locular, differentiated to the style. Style white, narrowly subclavate, erect, about as long as ovary. Stigma small. Capsule trilocular, loculicidal, ovoid to subglobose, erect, with remains of perigone circumscissile below and forming an apical cap, valves splitting to the base. Seeds black, flattened, distinctly winged with prominent embryo.

Etymology: The name of the new genus (greek; Tri-: three; Andros, - $a$ : male) refers to the three stamens per flower.
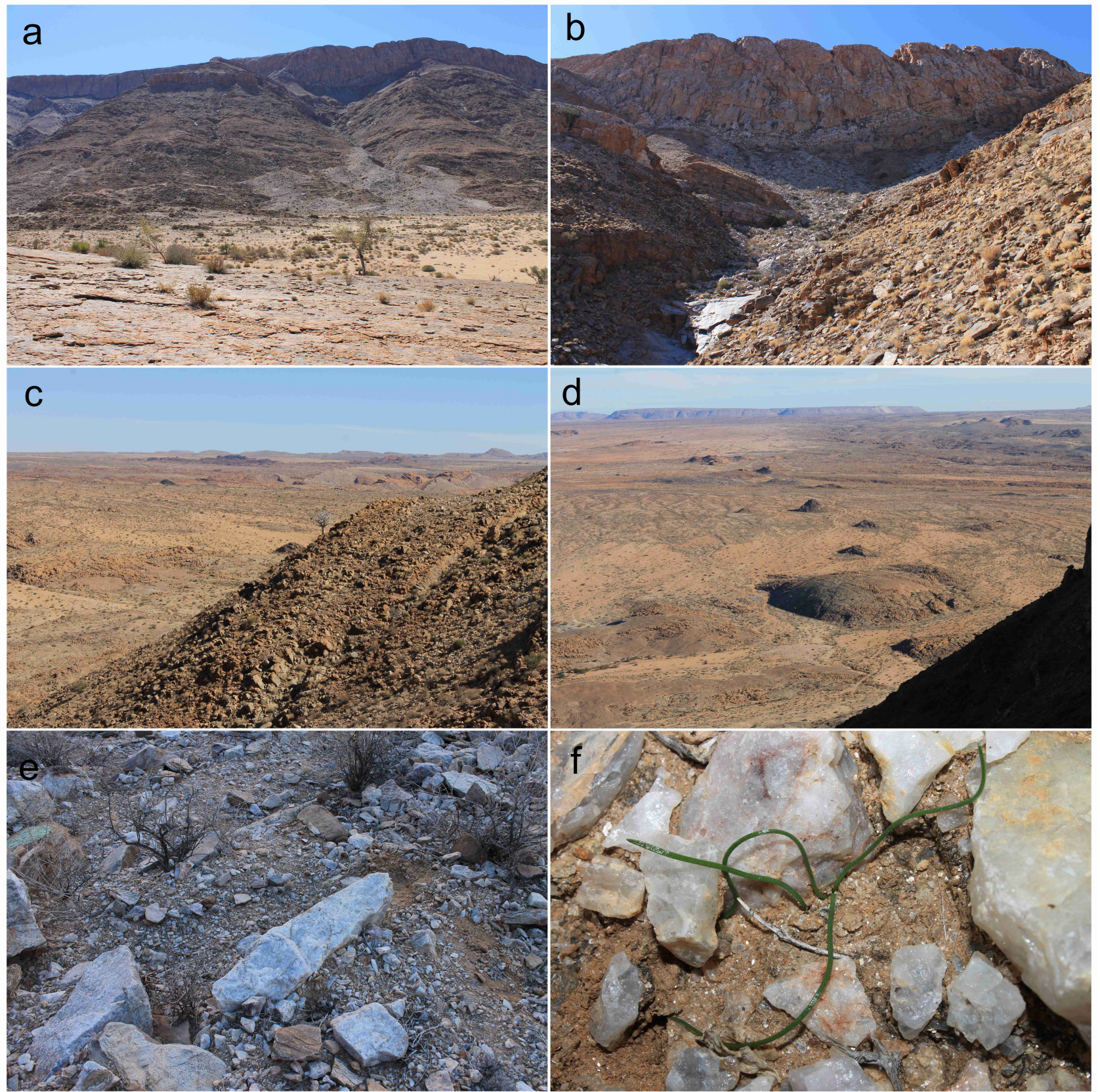

FIGURE 1. Habitat of Triandra pellabergensis Mart.-Azorín et al. at the type locality, Pella se Berge, Northern Cape Province (South Africa). a-b. Pella se Berge and south facing cliffs. c-d. Views to the southwest from the type locality showing the desert habitat. e-f. Gravelly quartzitic soil among boulders at the type locality and plant in habitat at vegetative stage on 14 August 2016. 
Triandra pellabergensis resembles Urginea revoluta in flower and leaf morphology, but the former species differs in consistently producing flowers with three stamens that are associated with the inner perianth whorl (not six, three also with the outer perianth whorl), and elliptical, flattened, winged seeds with a prominent embryo (not subpyramidal and irregularly compressed). Triandra occurs in the desert regions of northwestern South Africa, unlike U. revoluta which occurs in the fynbos vegetation of the southwestern Cape; phylogenetically, they represent distinct lineages.

Type:-SOUTH AFRICA. Northern Cape. Pofadder (2919): Pella, Pella se Berge, ca. $25 \mathrm{~km} \mathrm{~W}$ of Pofadder, rocky slopes at base of large south facing cliffs (-AA), 919 m elevation, among quartz and mica rocks, fl. ex hort. at University of Alicante on 29 June 2018, M. Martínez-Azorín, M.B. Crespo, M.Á. Alonso et al. MMA1671b (holotype: GRA; isotypes: $\mathrm{ABH}, \mathrm{K}, \mathrm{PRE})$.

Description:- Small, herbaceous, deciduous geophyte. Bulb hypogeal, ovoid to subglobose, $12-22 \times 8-18$ $\mathrm{mm}$, depressed in old plants, solitary, with compact, white, thickened scales, and pale brown, membranous to papery outer tunics. Roots fleshy, white, branched, $8-20 \times 0.5-1 \mathrm{~mm}$. Leaves $2-6$, proteranthous and withered at flowering time, narrowly linear-filiform, hypogeal portion white, 2-10 $\mathrm{mm}$ long, aerial portion bright green, $20-70 \times 0.8-1$ $\mathrm{mm}$, spreading, somewhat curved-sinuous, slightly fleshy-succulent, subterete to slightly flattened, glabrous, smooth. Inflorescence an erect, lax raceme, 30-60 mm long, with 4-7, long pedicellate flowers; peduncle at anthesis 30-50 $\mathrm{mm}$ long, greyish to purplish-brown, erect, glabrous, smooth, with minute paler maculae at base; pedicels 12-15 $\mathrm{mm}$ long at anthesis, spreading and curving downwards, smooth; bracts small, ovate-lanceolate, 0.6-0.9 mm long, clasping the pedicels, the lowermost with a spur ca. $0.4 \mathrm{~mm}$ long. Flowers pentacyclic, trimerous, stellate, nodding, opening by dusk and withering before sunrise, $1-3$ flowers open at a time, flower buds subcylindrical and somewhat constricted at the middle; tepals 6 , entire, whitish with a brownish-green longitudinal central band on the abaxial side, slightly glandulous at the apex, biseriate, outer overlapping inner at the base, free or very shortly connate for $0.2 \mathrm{~mm}$ at base, spreading and strongly reflexed at full anthesis; tepals monomorphic, 4.4-5.5 $\times 1-1.2 \mathrm{~mm}$, narrowly lanceolate, slightly narrowed in the central portion, canaliculate. Stamens 3, free, opposite to the inner tepals whorl, erect and connivent to the style at full anthesis (initially spreading after bud opening - see Fig. 2b,c,d, left sides- but soon becoming erect and connivent to the style); filaments white, filiform, subterete, ca. $4 \times 0.1 \mathrm{~mm}$, smooth; anthers yellow, ovate-oblong, ca. $0.3 \mathrm{~mm}$ long, dehiscing by longitudinal slits, with yellow pollen. Ovary pale yellow-green, ovate, truncate to the style, ca. $2 \times 1.2 \mathrm{~mm}$; style white, narrowly subclavate, erect, ca. $2.2 \times 0.1 \mathrm{~mm}$, subterete; stigma small, glandulose and minutely papillate. Capsule ovoid-globose, loculicidal, 4-4.5 $\times 3.5-4 \mathrm{~mm}$, valves splitting to the base, with the withered perigone segments circumscissile below and forming an apical cap. Seeds black, shining, $2-2.7 \times 1-1.2 \mathrm{~mm}$, ellipsoid, flattened with prominent embryo and distinctly winged, testa surface reticulate, loose and easily detachable from the endosperm.

Etymology:-Named after the type locality of the species, Pella se Berge in the northwestern Northern Cape Province of South Africa close to the Orange River and the border with Namibia (Fig. 1). This mountain site is a type locality shared by two other remarkable Hyacinthaceae, Bowiea gariepensis van Jaarsveld (1983: 343) and Eliokarmos craibii Martínez-Azorín et al. (2015: 69).

Phenology:-Triandra pellabergensis flowers from March to July in cultivation in the northern hemisphere and fruits appear from April to September. Leaves are proteranthous and completely withered at flowering time. Flowers are short-lived, opening by dusk and lasting few hours of a single night. In habitat, plants were in leaf in August (southern hemisphere Spring) at time of collection. Further studies are needed to evaluate its phenology in the wild.

Habitat:- This species is restricted to the Desert Biome and Eastern Gariep Rocky Desert (Dg 10) vegetation, growing in gravelly quartzitic soil among boulders, below south-facing large cliffs (Fig. 1) in positions that experience deep shade for most of the winter. The new species shares habitat with, among others, Bowiea gariepensis, Tylecodon sulphureus (Toelken 1977: 191) Toelken (1978: 381) subsp. armianus van Jaarsveld (1989: t. 1984) and Whiteheadia bifolia (Jacquin 1791: 215) Baker (1873b: 226). The region is characterized by annual precipitation ranging from 45 to $80 \mathrm{~mm}$, peaking in late summer and early autumn, becoming more pronounced eastwards. Summer maximum temperatures often exceed $40^{\circ} \mathrm{C}$, occasionally reaching $50^{\circ} \mathrm{C}$ at low elevations. Frost is very rare, but occurs at high elevations in the region (Mucina \& Rutherford 2006) where the type locality is located.

Distribution:-Triandra pellabergensis is only known from the type locality, in Pella se Berge, Northern Cape Province of South Africa (Fig. 1). Further research is needed to evaluate its full extent of occurrence, whilst cognisant of its cryptic character. 


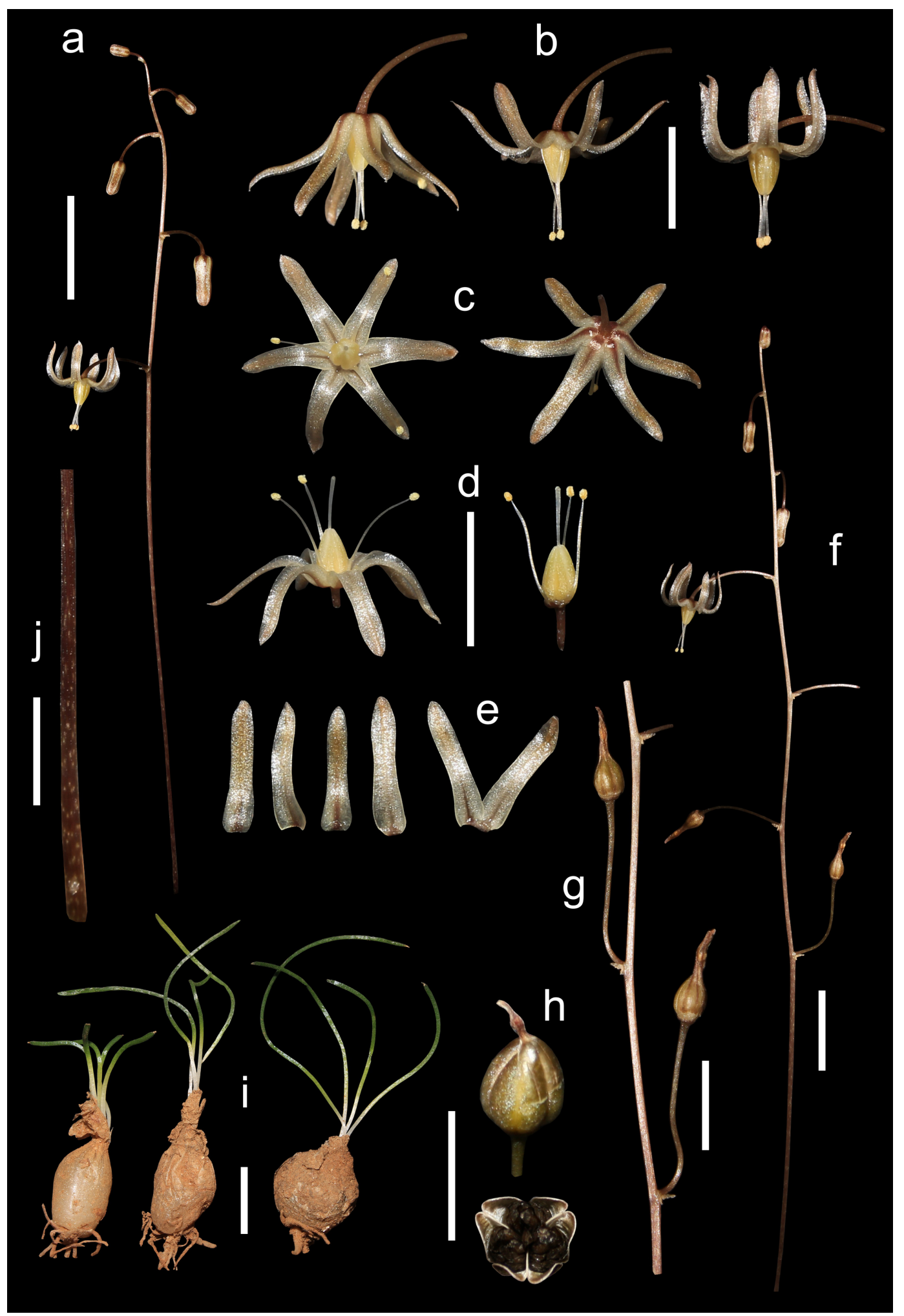

FIGURE 2. Triandra pellabergensis Mart.-Azorín et al. from the type locality, Pella se Berge (South Africa), ex hort. at University of Alicante in March 2017. a. Inflorescence; b. Flowers in lateral view, showing different stages of tepal disposition; c. Flowers in frontal and dorsal views; d. Flower with spreading stamens (left) and fertile portion of flower (right), showing the diagnostic 3 stamens; e. Tepals; $\mathrm{f}$. Inflorescence with immature capsules (one flower and part of its pedicel removed); g. Infructescence with erect capsules; h. Capsule with withered perianth cohering above, circumcissile below and forming an apical cap (above) and dehisced capsule showing seeds (below); i. Bulbs with leaves; j. Base of peduncle with slight maculation. Scale bars: a, f, i: $1 \mathrm{~cm}$; b-e, g, h: 5 mm; j: 3 mm. 

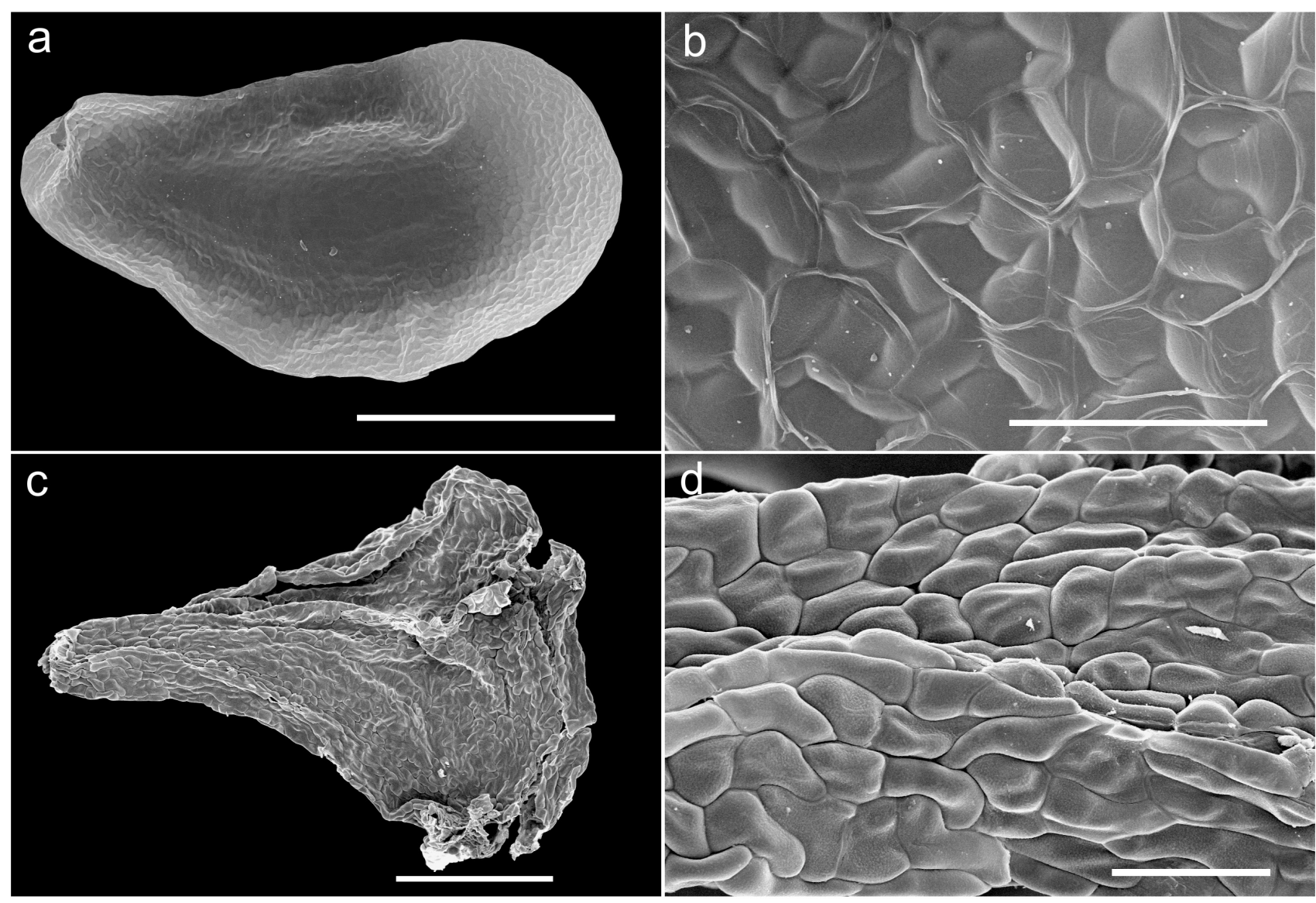

FIGURE 3. Seed morphology of Triandra pellabergensis Mart.-Azorín et al. (a-b) from the type locality, Pella se Berge (South Africa), and Urginea revoluta Baker (c-d) from Esterhuysen 22771 (BOL): Scale bars: a: 1 mm; b, d: $100 \mu \mathrm{m}$; c: $500 \mu \mathrm{m}$.

Diagnostic characters and taxonomic relationships:-Triandra pellabergensis is identified by the solitary bulb; the 2-6 proteranthous, filiform, glabrous, leaves; the lax raceme with 4-7, pedicellate, nodding, nocturnal flowers; the reflexed tepals at anthesis; the 3, erect stamens associated with the inner tepal whorl; the erect and narrowly subclavate style; the erect capsules with the withered tepals atop; and the flattened, winged seeds with prominent embryo (Fig. 2, 3a-b). The new species is unique in Hyacinthaceae in having only 3 stamens per flower, with those associated with the outer tepal whorl being absent. Some genera with very specialized flowers in Hyacinthaceae, like those of Albuca Linnaeus (1762: 438) (subfam. Ornithogaloideae), sometimes lack anthers on the 3 outer stamens, due to the specialized pollination mechanism (Johnson et al. 2012), although their filaments, which are sometimes reduced, are always present. We have observed various plants of Triandra pellabergensis in cultivation during the past three years and all individuals and flowers consistently produced 3 stamens, and lacked the outer staminal whorl.

The nodding nocturnal flowers with reflexed tepals of Triandra superficially resemble those of other genera in Urgineoideae, such as Thuranthos, Vera-duthiea or some species of Indurgia Speta (2001: 169). However, the latter genera clearly differ in androecial, gynoecial and vegetative structures (cf. Crouch et al. 2018, Martínez-Azorín et al. 2018b, 2019b, Yadav et al. 2019). Our phylogenetic studies (Martínez-Azorín et al. submitted) have revealed that the latter three genera represent independent evolutionary lineages which present considerable convergence in flower morphology, adapted as they are to night pollinators. The above-mentioned phylogenetic study place a sample of Triandra as sister to the Madagascan endemic genus Rhodocodon, from which it can be readily separated on morphological grounds (cf. Knirsch et al. 2015, 2016, 2019); these molecular analyses further reveal Triandra to be distantly related to Thuranthos, Vera-duthiea and Indurgia.

In overall morphology, Triandra pellabergensis approaches Urginea revoluta, a similar-looking species that occurs in the coastal mountains of the southern Western Cape Province. However, this latter species produces larger bulbs (to $4 \mathrm{~cm}$ in diam.); fewer (1-2) leaves per bulb, each leaf to $25 \mathrm{~cm}$ long; a longer and flexuous raceme with more numerous (5-20) flowers; larger tepals (6-9 mm long), pedicels (10-15 $\mathrm{mm}$ long) which are reflexed in flower and articulated in their middle; six stamens per flower with longer filaments (ca. $5 \mathrm{~mm}$ long); subclavate style with 
slightly capitate stigma; and notably angular, wrinkled seeds 2-2.5 mm long, with rugulose testa (Fig. 3c-d) (Duthie 1928, Manning \& Goldblatt 2018). Manning \& Goldblatt (2018) considered that Urginea revoluta is unique in the genus (Drimia, in their very broad sense covering nearly the whole subfamily Urgineoideae) in producing pedicels that abscise near the middle if the flowers are not pollinated, leaving a short, recurved basal portion 4-5 $\mathrm{mm}$ long attached to the scape, a character not observed in Triandra. There are also notable seed morphological differences between Triandra and $U$. revoluta, with those of the former being ellipsoidal, flattened and winged with a prominent embryo and reticulate testa (Fig. 3a-b), whilst in the latter they are subpyramidal, angular or irregularly compressed with a rugulose testa (Fig. 3c-d). We consider that the value of seed morphological characters has largely been understimated in the taxonomy and systematics of Urgineoideae. The current report well examples how two species that represent independent evolutionary lineages can show similar flower morphology (with covergence probably driven by nocturnal pollinators), and yet clearly differ in seed features (unconnected to pollination syndromes); both characters are widely used in other plant families to segregate genera. This is also evident when comparing angular or irregularly compressed seeds in genera such as Litanthus or Geschollia Speta (2001: 169), with those of genera (e.g. Urginavia, Thuranthos, Striatula, Vera-duthiea, etc.) that are better adapted to wind dispersal, being flattened and winged. Our unpublished phylogenetic analyses include a sample of $U$. revoluta from near Betty's Bay, Western Cape Province of South Africa, which resolves sister to a clade that includes Boosia macrocentra (Baker 1887: 702) Speta (2001: 169) and related taxa. The distinct genetic divergence between Urginea revoluta and Triandra (Martínez-Azorín et al. submitted) again indicates how the remarkable convergence of flower morphology may have been driven by nocturnal pollinators. To date, little work on pollinators of night-flowering urgineoids has been undertaken, but an extension of the work of Stirton (1976) should provide insights into the character of evolutionary processes that have led to the observed floral form convergence.

In summary, Triandra pellabergensis shows a unique syndrome of morphological characters within Urgineoideae, representing an independent evolutionary lineage for which a new genus is accordingly described.

\section{Additional material studied:}

Triandra pellabergensis (paratypes):- SOUTH AFRICA. Northern Cape. Pofadder (2919): Pella, Pella se Berge, ca. $25 \mathrm{~km} \mathrm{~W}$ of Pofadder, rocky slopes at base of large south facing cliffs (-AA), $919 \mathrm{~m}$ elevation, 14 August 2016 (vegetative), among quartz and mica rocks, M. Martínez-Azorín, M.B. Crespo, M.Á. Alonso et al. MMA1671 (ABH 74374 !).

Urginea revoluta:-SOUTH AFRICA. Western Cape. Worcester (3319): Worcester Division, Bailey's Peak, Bains Kloof, mts. stony E. slopes (-CA), 3000 feet elevation, after fire, 21 February 1954 (in fruit), E. Esterhuysen 22750 (BOL!); Worcester (3319): Paarl Division, Zuurvlakte, above Du Toitskloof, head of Pass (-CA), 3000 feet elevation, on stony plateau, after fire, 27 February 1954 (in fruit), E. Esterhuysen 22771 (BOL!); ibidem, grown at B.H., bulbs passed 15 November 1954, 7 March 1954 (in fruit), E. Esterhuysen 22771 (BOL!); Simonstown (3418): Stellenbosch Division, burnt stony slope above Diepgat, Somerset West (-BB), 1500-2000 feet elevation, 8 January 1950 (in flower), E. Esterhuysen 16727 (BOL!); Simonstown (3418): Fairy Glen, Palmiet River mouth (-BD), 450 feet elevation, 7 December 1896 (in flower), H. Bolus s.n. (BOL!); Simonstown (3418): Caledon Division, mts. near Palmiet River mouth, lower south slopes (-BD), 25 January 1947 (in flower), E. Esterhuysen 13672 (BOL! two sheets); Simonstown (3418): Caledon Division, Palmiet River (-BD), in rock crevices on river bank, 29 December 1941 (in flower), F.M. Leighton sub BOL22719 (BOL!, NBG!); Simonstown (3418): Kogelberg Reserve, Oudebos, across Palmiet River (-BD), rocky soil, sand, fynbos, recently burned, 6 January 2001 (in flower), J.C. Manning 2303 (NBG!, 2 sheets); Simonstown (3418): Simostown, Kogelberg State Forest, Dwars River Mountain, foothills near Somersfontein (-BD), ca. 300 m elevation, dry flat coarse sandy soil, burnt September 1971, 12 January 1973 (in flower), C. Boucher 2063 (PRE barcode 0734884!); Simonstown (3418): Kogelberg S.F., Kogelberg Research Site, burnt plot KBE3 (-BD), ca. 120 m elevation, washed out TMS, deep soil, 16 March 1977, B.J. Durand 189 (PRE barcode 0813763!); Simonstown (3418): Caledon Division, mt. slopes at Rooi Els (-BD), 5 February 1947 (in flower), E. Esterhuysen 13714 (BOL!); Caledon (3419): circa Elim, district Bredasdorp (-DA or -DB), ca. 20 m elevation, coarse sandy soil on $15^{\circ}$ slope, area burnt September 1971, 8 January 1972 (in flower), C. Boucher 1776 (BOL!, PRE barcode 0240617!); Caledon (3419): Caledon Division, Riviersonderend Mts., slopes near R. Z. E. village, after fire, 20 November 1955 (in flower and fruit), E. Esterhuysen 25329 (BOL!); Caledon (3419): Fernkloof Nature Reserve, Hermanus (-AD) (Photo! https://www.fernkloof.org.za/index.php/all-plants/plant-families/item/drimia-hesperantha); Caledon (3419): Hemel \& Aarde Valley, Hermanus, Overberg District Municipality (-AD), -34.389903 S 19.255905 E, 14 February 2020, D. Marais (photos! https://www.inaturalist.org/observations/38629796); Caledon (3419): 
Phillipskop Mountain Reserve (-AD), -34.40353 S 19.5319978 E, 8 March 2019, C. Whitehouse (Photos! https://www. inaturalist.org/observations/21261605); Caledon (3419): Sandberg Fynbos Reserve (-DA), -34.599068 S 19.678738 E, 17 January 2019, J. Deacon (Photos! https://www.inaturalist.org/observations/19825761); Bredasdorp (3420): De Hoop, near turn off from Potberg road (-AD), foot of limestone hills, 6 February 1998 (in flower), P. Goldblatt \& J.C. Manning 10857 (NBG!, MO).

\section{Acknowledgements}

We thank the curators of the herbaria who provided access to the specimens examined and to Cornelia Klak (Bolus Herbarium) for permission to sample seed of Urginea revoluta from a BOL accession. The Department of Environment and Nature Conservation of Northern Cape Province (collecting and export permits numbers FLORA046/2010, FLORA047/2010, FLORA069/2011, FLORA070/2011, FLORA61/2/2015, FLORA62/2/2015, FLORA0057/2017, FLORA0058/2017) provided permission to collect herbarium specimens to the first author and collaborators. This work was partly supported by H2020 Research and Innovation Staff Exchange Programme of the European Commission, project 645636: 'Insect-plant relationships: insights into biodiversity and new applications' (FlyHigh), and the grants ACIE18-03 UAUSTI18-02 and UAUSTI19-08 from the University of Alicante.

\section{References}

Angiosperm Phylogeny Group (2003) An update of the Angiosperm Phylogeny Group classification for the orders and families of flowering plants: APG II. Botanical Journal of the Linnean Society 141: 399-436.

https://doi.org/10.1046/j.1095-8339.2003.t01-1-00158.x

Angiosperm Phylogeny Group (2009) An update of the Angiosperm Phylogeny Group Classification for the orders and families of flowering plants: APG III. Botanical Journal of the Linnean Society 161: 105-121.

https://doi.org/10.1111/j.1095-8339.2009.00996.x

Angiosperm Phylogeny Group (2016) An update of the Angiosperm Phylogeny Group Classification for the orders and families of flowering plants: APG IV. Botanical Journal of the Linnean Society 181: 1-20. https://doi.org/10.1111/boj.12385

Baker, J.G. (1873a) On Schizobasis, a new genus of Liliaceae from Cape Colony. Journal of Botany, British and Foreign 11: 105.

Baker, J.G. (1873b) Revision of the genera and species of Scilleae and Chlorogaleae. Journal of the Linnean Society, Botany 13: 209292.

Baker, J.G. (1880) Notes on a collection of flowering plants made by L. Kitching, Esq., in Madagascar in 1979. Journal of the Linnean Society, Botany 18: 264-281. https://doi.org/10.1111/j.1095-8339.1881.tb01257.x

Baker, J.G. (1887) New or noteworthy plants. The Gardener's Chronicle: a weekly illustrated journal of horticulture and allied subjects, ser. 3, 1: 702 .

Chase, M.W., Reveal, J.L. \& Fay, M.F. (2009) A subfamilial classification for the expanded asparagalean families, Amaryllidaceae, Asparagaceae and Xanthorrhoeaceae. Botanical Journal of the Linnean Society 161: 132-136. https://doi.org/10.1111/j.1095-8339.2009.00999.x

Crouch, N.R. \& Martínez-Azorín, M. (2015) Drimia edwardsii (Asparagaceae, Scilloideae), a new urgineoid species from the Mkhomazi River Valley of eastern South Africa. Phytotaxa 195: 135-144. https://doi.org/10.11646/phytotaxa.195.2.2

Crouch, N.R., Martínez-Azorín, M., Crespo, M.B., Pinter, M. \& Alonso-Vargas, M.Á. (2018) Zingela (Asparagaceae, Scilloideae), a distinct new urgineoid genus from KwaZulu-Natal, South Africa. Phytotaxa 371: 33-41.

https://doi.org/10.11646/phytotaxa.371.1.4

Duthie, A.V. (1928) Contribution to our knowledge of the Stellenbosch Flora. The species of Urginea of the Stellenbosch Flats. Annale van die Universiteit van Stellenbosch 6, Sect. A, 2: 3-16.

Harvey, W.H. (1844) Litanthus, a new genus of Asphodeleae from South Africa. The London Journal of Botany 3: 314-315.

Hooker, J.D. (1867) Bowiea volubilis. Curtis's Botanical Magazine Ser. 3, 23: t. 5619.

IPNI (2021) The international plant names index. Available from http://www.ipni.org (continuously updated; accessed November 2021) Jacquin, N.J. (1791) Collectanea ad Botanicam, Chemiam, et Historiam Naturalem, Spectantia, cum Figuris 4. Wappler, C.F., Vindobonae, 359 pp. 
Johnson, S.D., Jürgens, A. \& Kuhlmann, M. (2012) Pollination function transferred: modified tepals of Albuca (Hyacinthaceae) serve as secondary stigmas. Annals of Botany 110: 565-572.

https://doi.org/10.1093/aob/mcs114

Knirsch, W., Martínez-Azorín, M., Pfosser, M. \& Wetschnig, W. (2015) The reinstatement and rediagnosis of the Madagascan genus Rhodocodon (Asparagaceae, Scilloideae), with validation and remarks on H. Perrier's taxa. Phytotaxa 195: 101-134. https://doi.org/10.11646/phytotaxa.195.2.1

Knirsch, W., Martínez-Azorín, M., Brudermann, A., Pfosser, M. \& Wetschnig, W. (2016) Rhodocodon jackyi (Asparagaceae, Scilloideae), a new species from Madagascar related to R. urgineoides. Phytotaxa 253: 201-206. https://doi.org/10.11646/phytotaxa.253.3.3

Knirsch, W., Martínez-Azorín, M., Pfosser, M., Brudermann, A., Andriantiana, J. \& Wetschnig, W. (2019) Five new species of Rhodocodon (Asparagaceae, Scilloideae) from Madagascar. Phytotaxa 414: 129-145. https://doi.org/10.11646/phytotaxa.414.3.2

Linnaeus, C. (1762) Species plantarum. ed. 2. Salvius, Stockholm, 784 pp.

Leistner, O.A. \& Morris, J.W. (1976) Southern African place names. Annals of the Cape Provincial Museum 12: 1-565.

Manning, J.C. \& Goldblatt, P. (2003) A new species and new combinations in Drimia (Urgineoideae). Bothalia 33: 109-111. https://doi.org/10.4102/abc.v33i1.2299

Manning, J.C. \& Goldblatt, P. (2018) Systematics of Drimia Jacq. (Hyacinthaceae: Urgineoideae) in southern Africa. Strelitzia 40. South African National Biodiversity Institute, Pretoria, $173 \mathrm{pp}$.

Manning, J.C., Goldblatt, P. \& Fay, M.F. (2004) A revised generic synopsis of Hyacinthaceae in Sub-Saharan Africa, based on molecular evidence, including new combinations and the new tribe Pseudoprospereae. Edinburgh Journal of Botany 60: 533-568. https://doi.org/10.1017/S0960428603000404

Manning, J.C., Forest, F., Devey, D.S., Fay, M.F. \& Goldblatt, P. (2009) A molecular phylogeny and a revised classification of Ornithogaloideae (Hyacinthaceae) based on an analysis of four plastid DNA regions. Taxon 58: 77-107. https://doi.org/10.1002/tax.581011

Martínez-Azorín, M., Crespo, M.B. \& Juan, A. (2007) Taxonomic revision of Ornithogalum subg. Cathissa (Salisb.) Baker (Hyacinthaceae). Anales del Jardín Botánico de Madrid 64: 7-25. https://doi.org/10.3989/ajbm.2007.v64.i1.47

Martínez-Azorín, M., Crespo, M.B. \& Juan, A. (2009) Taxonomic revision of Ornithogalum subg. Beryllis (Hyacinthaceae) in the Iberian Peninsula and the Balearic Islands. Belgian Journal of Botany 142: 140-162. https://doi.org/10.2307/41427183

Martínez-Azorín, M., Crespo, M.B., Juan, A. \& Fay, M.F. (2011) Molecular phylogenetics of subfamily Ornithogaloideae (Hyacinthaceae) based on nuclear and plastid DNA regions, including a new taxonomic arrangement. Annals of Botany 107: 1-37. https://doi.org/10.1093/aob/mcq207

Martínez-Azorín, M., Crespo, M.B., Dold, A.P., Wetschnig, W., Pinter, M., Pfosser, M. \& van Jaarsveld, E. (2013) Sagittanthera (Hyacinthaceae, Urgineoideae), a new buzz pollinated genus from the Eastern Cape Province of South Africa. Phytotaxa 98: 4354.

http://dx.doi.org/10.11646/phytotaxa.98.2.2

Martínez-Azorín, M., Crespo, M.B., Pinter, M. \& Wetschnig, W. (2015) Eliokarmos craibii (Asparagaceae, Scilloideae), a new species from Pella se Berge, Northern Cape Province, South Africa. Phytotaxa 204: 65-74. http://dx.doi.org/10.11646/phytotaxa.204.1.5

Martínez-Azorín, M., Crespo, M.B., Pinter, M. \& Wetschnig, W. (2017) Aulostemon (Asparagaceae, Scilloideae), a new genus from South Africa. Phytotaxa 321: 287-293.

https://doi.org/10.11646/phytotaxa.321.3.6

Martínez-Azorín, M., Crespo, M.B., Alonso-Vargas, M.Á., Dold, A.P., Pinter, M. \& Wetschnig, W. (2018a) Austronea (Asparagaceae, Scilloideae), a new genus from southern Africa, including the description of seven new species. Phytotaxa 365: 101-129. https://doi.org/10.11646/phytotaxa.365.2.1

Martínez-Azorín, M., Crouch, N.R. \& Crespo, M.B. (2018b) Vera-duthiea zebrina (Asparagaceae, Scilloideae), a new species from eastern South Africa, and a first genus record for southern Africa. Phytotaxa 375: 283-289. https://doi.org/10.11646/phytotaxa.375.4.4

Martínez-Azorín, M. Crespo, M.B., Pinter, M., Slade, J.M. \& Wetschnig, W. (2019a) Iosanthus (Hyacinthaceae subfam. Urgineoideae), a new genus from southern Africa to include Ornithogalum toxicarium and its removal from Ornithogaloideae. Plant Biosystems 153 (4): $580-588$.

https://doi.org/10.1080/11263504.2018.1527793 
Martínez-Azorín, M., Crespo, M.B., Alonso-Vargas, M.Á., Dold, A.P., Crouch, N.R., Pfosser, M., Mucina, L., Pinter, M. \& Wetschnig, W. (2019b) New combinations in the tribe Urgineeae (Asparagaceae subfam. Scilloideae) with comments on contrasting taxonomic treatments. Phytotaxa 397 (4): 291-299.

https://doi.org/10.11646/phytotaxa.397.4.3

Mucina, L. \& Rutherford, M.C. (Eds.) (2006) The vegetation of South Africa, Lesotho and Swaziland. Strelitzia 19. South African National Biodiversity Institute, Pretoria, $807 \mathrm{pp}$.

Pfosser, M. \& Speta, F. (1999) Phylogenetics of Hyacinthaceae based on plastid DNA sequences. Annals of the Missouri Botanical Garden 86: 852-875. https://doi.org/10.2307/2666172

Pfosser, M. \& Speta, F. (2001) Bufadienolide und DNA-Sequenzen: Über Zusammenhalt und Aufteilung der Urgineoideae (Hyacinthaceae). Stapfia 75: 177-250.

Pfosser, M. \& Speta, F. (2004) From Scilla to Charybdis - is our voyage safer now? Plant Systematics and Evolution 246: $245-263$. https://doi.org/10.1007/s00606-004-0153-z

Pfosser, M., Knirsch, W., Pinter, M., Ali, S., Dutta, S. \& Wetschnig, W. (2012) Phylogenetic relationships of Malagasy Hyacinthaceae. Plant Ecology and Evolution 145: 65-72. https://doi.org/10.5091/plecevo.2012.590

Pinter, M., Crespo, M.B., Ilg, I., Luidold, A.K., Martínez-Azorín, M., Müller-Doblies, U., Müller-Doblies, D., Pfosser, M. \& Wetschnig, W. (2013) Mucinaea (Hyacinthaceae-Urgineoideae), a remarkable new genus from Namaqualand (Northern Cape Province, South Africa). Phyton (Horn, Austria) 53 (2): 289-304.

Pinter, M., Martínez-Azorín, M., Crespo, M.B., Alonso-Vargas, M.Á. \& Wetschnig, W. (2019) Striatula (Hyacinthaceae, Urgineoideae), a new genus from South Africa and southern Namibia. Phyton (Horn, Austria) 59 (1-2): 91-98. https://doi.org/10.12905/0380.phyton59-2019-0091

Rafinesque, C.S. (1837) Flora Telluriana 3. H. Probasco, Philadelphia, 100 pp.

Salisbury, R.A. (1866) The genera of plants: a fragment containing part of Liriogamae. John van Voorst, London, 143 pp.

Speta, F. (1998a) Hyacinthaceae. In: Kubitzki, K. (Ed.) The families and genera of vascular plants 3. Springer, Berlin, 261-285. https://doi.org/10.1007/978-3-662-03533-7_35

Speta, F. (1998b) Systematische Analyse der Gattung Scilla L. s.l. (Hyacinthaceae). Phyton (Horn, Austria) 38 (1): 1-141.

Speta, F. (2001) Die echte und die falsche Meerzwiebel: Charybdis Speta und Stellarioides Medicus (Hyacinthaceae), mit Neubeschreibungen und Neukombinationen im Anhang. Stapfia 75: 139-176.

Speta, F. (2016) Substitution of an illegitimate generic name in Hyacinthaceae, and validation of names of already described species in Ornithogalum (Hyacinthaceae) and Pinguicula (Lentibulariaceae). (Edited by Gutermann, W. \& Speta, E.). Phyton (Horn, Austria) 56 (2): 153-159.

https://doi.org/10.12905/0380.phyton56(2)-2016-0153

Steinheil, A. (1834) Note sur le genre Urginea nouvellement formé dans la famille des Liliacées. Annales des Sciences Naturelles, Botanique, Sér. 2, 1: 321-332.

Stirton, C.H. (1976) Thuranthos, notes on generic status, morphology, phenology and pollination biology. Bothalia 12: 161-165. https://doi.org/10.4102/abc.v12i1.1389

Thiers, B. (2021) Index Herbariorum: A global directory of public herbaria and associated staff. New York Botanical Garden's Virtual Herbarium. Available at http://sweetgum.nybg.org/ih/ (continuously updated; accessed November 2021)

Toelken, H.R. (1977) New taxa and a new combination in the genus Cotyledon. Bothalia 12: 191-194.

Toelken, H.R. (1978) New taxa and combinations in Cotyledon and allied genera. Bothalia 12: 377-393.

van Jaarsveld, E.J. (1983) Bowiea gariepensis: a new Bowiea species (Liliaceae) from the North Western Cape. Journal of South African Botany 49: 343-346.

van Jaarsveld, E.J. (1989) Tylecodon sulphureus var. armianus. Flowering Plants of Africa 50: t. 1984.

Willdenow, C.L. (1799) Caroli a Linné Species Plantarum. Editio Quarta, vol. 2 (1). Impensis G.C. Nauk, Berolini [Berlin], 823 pp.

Wright, C.H. (1916) Diagnoses africanae: LXIX. Bulletin of Miscellaneous Information, Royal Gardens, Kew 1916: 229-235. https://doi.org/10.2307/4114331

Yadav, P.B., Manning, J.C., Yadav, S.R. \& Lekhak, M.M. (2019) A cytotaxonomic revision of Drimia Jacq. (Hyacinthaceae: Urgineoideae) in India. South African Journal of Botany 123: 62-86.

https://doi.org/10.1016/j.sajb.2019.01.018 